06

\title{
Влияние углеродных нанотрубок на электрические и механические свойства хитозановых пленок
}

\author{
() А.М. Камалов, ${ }^{1}$ В.В Кодолова-Чухонцева, ${ }^{1}$ Е.Н Дресвянина, ${ }^{1,2}$ Т.П Масленникова, ${ }^{3}$ И.П Добровольская, ${ }^{1,4}$ \\ Е.М Иванькова, ${ }_{4}^{4}$ Е.Н Попова, ${ }_{4}^{4}$ В.Е Смирнова, ${ }_{4}^{4}$ В.Е Юдин ${ }^{1,4}$ \\ ${ }^{1}$ Санкт-Петербургский политехнический университет Петра Великого, \\ 195251 Санкт-Петербург, Россия \\ ${ }^{2}$ Санкт-Петербургский государственный университет промышленных технологий и дизайна, \\ 191186 Санкт-Петербург, Россия \\ ${ }^{3}$ Институт химии силикатов им. И.В. Гребенщикова РАН, \\ 199034 Санкт-Петербург, Россия \\ ${ }^{4}$ Институт высокомолекулярных соединений РАН, \\ 199004 Санкт-Петербург, Россия \\ e-mail: spb.kamalov@gmail.com
}

Поступило в Редакцию 14 октября 2021 г.

В окончательной редакции 22 ноября 2021 г.

Принято к публикации 23 ноября 2021 г.

Методами рентгеновской дифракции и сканирующей электронной микроскопии проведено исследование структуры композитных пленок на основе хитозана и одностенных углеродных трубок. Показано, что введение углеродных нанотрубок приводит к упорядочению структуры хитозана. При увеличении содержания нанотрубок от 0 до $3 \%$ происходит рост модуля упругости с 3 до $4 \mathrm{GPa}$, увеличение электропроводности от $10^{-11}$ до $10^{2} \mathrm{~S} / \mathrm{m}$, изменение диэлектрической проницаемости от 5.5 до 26 на $1 \mathrm{kHz}$. Приведены данные о ионной и электронной составляющих проводимости композитной пленки.

Ключевые слова: хитозан, электропроводность, нанотрубки, диэлектрическая проницаемость, композит.

DOI: $10.21883 / J T F .2022 .03 .52138 .278-21$

\section{Введение}

В последнее время полимерные материалы активно используются в клеточных технологиях, регенеративной медицине, а также в производстве медицинских устройств для диагностики и лечения различных заболеваний. Пленки, волокна и блочные пористые материалы, используемые в биомедицинских технологиях, должны обладать не только биосовместимостью, а также комплексом характеристик, которые обеспечивают их биомиметические свойства и специфическую биологическую активность. Это достигается максимальным приближением структуры, а также прочностных, деформационных и электрофизических свойств материала к характеристикам тканей живого организма [1]. Также показано, что эффективной технологией регуляции поведения клеток является электрическая стимуляция с помощью электропроводящих материалов [2].

Биосовместимые полимеры, такие как полилактид, полигликолид и их сополимеры, а также хитозан могут быть использованы в качестве основы для биологически активных композитных материалов. Большинство полимеров обладают диэлектрическими свойствами, вместе с тем в последние годы разработаны электропроводящие композитные материалы, содержащие в качестве наполнителей такие компоненты, как углеродные частицы различной формы и размеров - углеродные волокна, технический углерод [3], а также углеродные нанотрубки, нановолокна, графен [4]. В качестве электропроводящей компоненты могут быть использованы также электропроводящие полимеры, в частности, полипиррол [4-6].

Одностенные углеродные нанотрубки (ОСУНТ) являются перспективным наполнителем для композитных материалов различного назначения, их добавление позволяет регулировать механические, электрические и термические характеристики материала. ОСУНТ применяют в качестве носителей лекарственных средств [7-9], получения биосенсоров, матриц для клеточных технологий и тканевой инженерии $[4,10,11]$. В последнее время они эффективно используются в качестве наполнителей электропроводящих композитных материалов [4], конструкций для эффективного управления ростом нейритных стволовых клеток $[11,12]$.

Кроме реакций клеток, которые традиционно считались электрочувствительными, описано воздействие электростимуляции на культуру дермальных фибробластов человека с целью повышения эффективности регенерации кожи и мягких тканей [13].

В пользу электрочувствительности дермальных фибробластов говорят и данные о том, что поддержание постоянного электрического потенциала между внешним и внутренним слоями кожи - необходимое условие для ее гомеостаза, а в случае повреждений покровов, электрические сигналы координируют процессы регенерации [14]. 
Хитозан является одним из перспективных полимеров для использования в качестве матрицы нанокомпозитов для кожных регенеративных технологий. Являясь производным полисахарида хитина, он обладает полным спектром биологических свойств таких, как биосовместимость, биоактивность, биорезорбируемость, антибактериальная, ранозаживляющая и гемостатическая активность [15]. Хотя материалы на основе хитозана обладают полезными лечебными характеристиками, они не обладают необходимым уровнем электропроводности. Вместе с тем электрические сигналы участвуют в клеточных коммуникациях, сопровождающих регенерацию тканей. Поэтому матрицы для тканевой инженерии должны иметь определенный уровень электропроводности, чтобы повысить их биосовместимость, стимулировать клеточные процессы, способствовать адгезии, пролиферации и дифференцировке клеток [16,17].

Введение ОСУНТ в количестве, не превышающем 10 wt.\%, в матрицу на основе хитозана позволяет существенно повысить электропроводность материала, его прочностные и упругие характеристики $[6,18]$. При этом низкое содержание наполнителя и его стабильное взаимодействие с полимером позволяют минимизировать его потенциальную цитотоксичность.

Целью настоящей работы являлась разработка электропроводящих композитных пленок на основе хитозана и ОСУНТ, а также исследование их структуры, электрофизических, физико-механических и термических свойств.

\section{1. Материалы и методы}

Композитные пленки получали из смеси ОСУНТ с $4 \%$-ным раствором хитозана в $2 \%$-ой уксусной кислоте. Использовали хитозан фирмы Biolog Нерре GmbH, Германия, с молекулярной массой $M_{m}=(1.64-2.1) \cdot 10^{5}$, и степенью деацетилирования $D D=92 \%$. Диаметр ОСУНТ, производства Carbon Chg, Россия, составлял $1.4 \pm 0.3 \mathrm{~nm}$, а длина $1-5 \mu \mathrm{m}$. Водную дисперсию, содержащую ОСУНТ, обрабатывали ультразвуком с помощью диспергатора IL10-0.63 в течение $15 \mathrm{~min}$ при частоте $25 \mathrm{kHz}$ и мощности $630 \mathrm{~W}$. Хитозан вводили в водную дисперсию ОСУНТ в количестве, обеспечивающем концентрацию полимера в растворе $4.0 \mathrm{wt} \%$ и требуемое соотношение хитозан/ОСУНТ.

Смесь хитозана и ОСУНТ перемешивали в воде в течение $30 \mathrm{~min}$ до набухания и частичного растворения хитозана. Затем в полученную смесь вводили уксусную кислоту; ее концентрация в растворе составляла $2 \%$. Раствор перемешивали в течение $180 \mathrm{~min}$, затем фильтровали и деаэрировали в вакуумной камере в течение $24 \mathrm{~h}$ при давлении $10 \mathrm{kPa}$. Содержание ОСУНТ составляло $0.1,0.5,1.0,3.0 \mathrm{wt} . \%$. по отношению к хитозану. Пленки отливали путем экструзии раствора через щелевую фильеру на стеклянную подложку, высушивали при температуре $50^{\circ} \mathrm{C}$ в течение $1 \mathrm{~h}$. Далее пленки на стеклянной подложке деаэрировали в вакуумной камере в течение $24 \mathrm{~h}$ при давлении $10 \mathrm{kPa}$ и затем сушили на воздухе при комнатной температуре в течение $24 \mathrm{~h}$. Для превода пленок из солевой в основную форму их выдерживали в смеси 10\%-ного водного раствора $\mathrm{NaOH}$ и $\mathrm{C}_{2} \mathrm{H}_{5} \mathrm{OH}$ с соотношением компонентов $1: 1$ в течение $10 \mathrm{~min}$, затем промывали дистиллированной водой и сушили на воздухе. Толщина пленок составляла $30 \pm 5 \mu \mathrm{m}$.

Исследование структуры нанокомпозитных хитозановых пленок в основной форме проводили с помощью методов сканирующей электронной микроскопии. Измерения проводили на приборе SUPRA-55VP (Carl Zeiss, Германия).

Анализ кристаллической структуры хитозановых и композитных пленок проводили на дифрактометре ДРОН-3М (НПО „Буревестник“) в режиме „на отражение“ с использованием $\mathrm{Cu} K_{\alpha}$-излучения. Съемку вели в интервале углов $2 \theta=10-75^{\circ}$ с шагом $0.02^{\circ}$ при экспозиции в каждой точке $1 \mathrm{~s}$. Обработку полученных данных и идентификацию пиков проводили с использованием пакета программы DFWin и базы данных ICDD PDF-2.

Электрическую проводимость измеряли в изотермических условиях при $25^{\circ} \mathrm{C}$ с помощью пикоамперметра Keithley 6487, использовали как 2-х электродную, так и 4-х электродную схемы. Диэлектрические спектры получали на широкополосном диэлектрическом спектрометре Concept 22 компании Novocontrol Technologies с автоматическим частотным анализатором высокого разрешения ALPHA-ANB. Величины диэлектрической проницаемости и потерь были получены в диапазоне частот от $1 \mathrm{~Hz}$ до $1 \mathrm{MHz}$, амплитуда измерительного сигнала составляла $1 \mathrm{~V}$. Предварительно на образцы напыляли платиновые электроды толщиной $10 \mathrm{~nm}$. Образцы помещали между двумя параллельными пластинчатыми электродами.

Механические свойства исследовали на приборе Instron 5943, база испытания $10 \mathrm{~mm}$, скорость растяжения образца $10 \mathrm{~mm} / \mathrm{min}$. Перед испытаниями образцы пленок из хитозана и композитных пленок выдерживали в эксикаторе при относительной влажности воздуха $66 \%$ не менее $24 \mathrm{~h}$.

Температурные зависимости модуля упругости $\left(E^{\prime}\right)$ и тангенса угла механических потерь $(\operatorname{tg} \delta)$ пленок из хитозана и композитных пленок исследовали методом ДМА на установке DMA 242C/1/F (Netzsch, Германия). Измерения проводили в процессе нагревания от 20 до $320^{\circ} \mathrm{C}$ со скоростью $5^{\circ} \mathrm{C} / \mathrm{min}$ при частоте нагружения $v=1 \mathrm{~Hz}$, амплитуде деформации $0.1 \%$, базовая длина составляла $10 \mathrm{~mm}$. По температурам максимумов кривых $\operatorname{tg} \delta$ определены температуры основных релаксационных переходов образцов.

Термические свойства исследовали методом термогравиметрического анализа (ТГА) на приборе фирмы NETZSCH, марки TG 209F1 (Германия). Испытания проводили в диапазоне температур от 30 до $800^{\circ} \mathrm{C}$ при скорости нагрева $10^{\circ} \mathrm{C} / \mathrm{min}$ в среде аргона. Масса образца 2-3 mg. В результате определяли остаточную 
массу при $800^{\circ} \mathrm{C}$ и рассчитывали индексы термостойкости $\left(\tau_{5}, \tau_{10}\right)$, значения которых соответствуют температурам 5 и $10 \%$ потери массы образцов.

\section{2. Результаты и их обсуждение}

Исследование сруктуры композитных материалов проводили с помощью рентгеновской дифракции и сканирующей электронной микроскопии. Дифрактограммы пленок из хитозана и композитных пленок с различным содержанием ОСУНТ представлены на рис. 1. Видно, что для пленки из хитозана в основной форме характерно наличие двух широких дифракционных максимумов на углах $2 \theta=10$ и $20^{\circ}$, что согласуется с данными, приведенными в работе [19]. Введение в хитозановую матрицу ОСУНТ приводит к росту интенсивности максимума хитозана на угле $2 \theta=15^{\circ}$, что указывает на увеличение упорядоченности кристаллических областей хитозана, в частности, увеличение доли распрямленных цепей, уменьшение расстояния между ними.

Появление углеродного рефлекса [002] на угле $2 \theta=26.5^{\circ}$, рост его интенсивности свидетельствует о наличии ОСУНТ в композитных пленках, увеличении их концентрации. Это подтверждают результаты СЭМисследований, приведенные на рис. 2.

Из микрофотографий сколов в жидком азоте хитозановой пленки и композитных пленок, содержащих ОСУНТ, приведенных на рис. 2, следует, что структура хитозановой пленки (рис. 2, $a, b)$ характеризуется наличием слоистых элементов, что согласуется с данными, приведенными в работах [20,21]. Введение 0.5 wt.\% ОСУНТ (рис. 2, $c, d$ ) приводит к более плотной, гомогенной структуре пленки. Это подтверждают результаты рентгеноструктурного анализа, появление дифракционного максимума хитозана на угле $2 \theta=15^{\circ}$ (рис. 1).

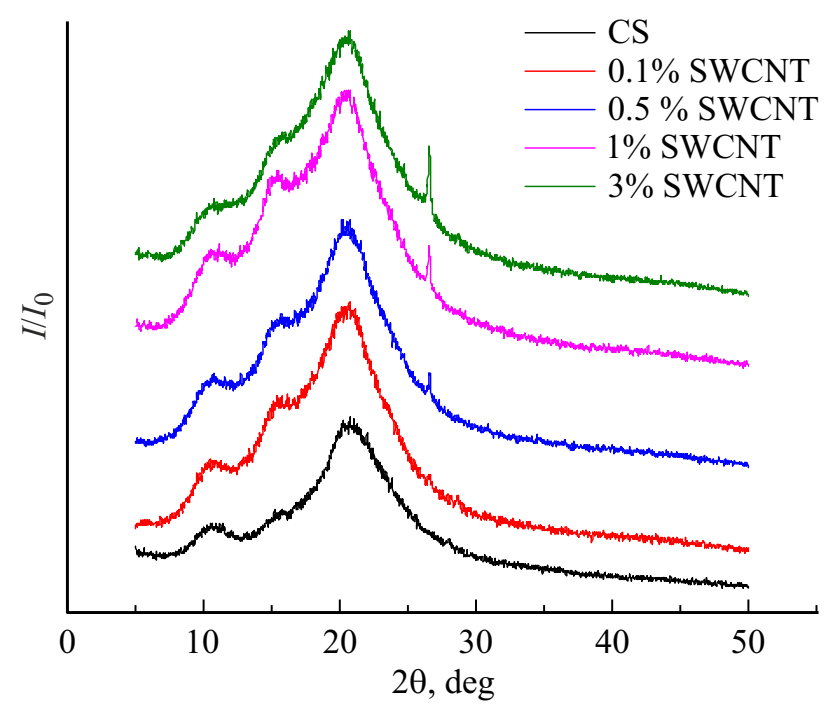

Рис. 1. Рентгеновские дифрактограммы пленки из хитозана (нижняя кривая) и композитных пленок с различным содержанием ОСУНТ (остальные кривые).
При увеличении содержания ОСУНТ до $1.0 \mathrm{wt} . \%$ на сколе видны отдельные углеродные нанотрубки (рис. 2,e,f). Количество нанотрубок на поверхности скола возрастает при введении $3 \%$ ОСУНТ (рис. $2, g, h$ ). Насыщенность углеродными нанотрубками хитозановой матрицы приводит к формированию сетки из ОСУНТ, их расположению в плоскости пленки, а также нормалью к плоскости хитозановой матрицы, что отчетливо видно на рис. 2 , h. Такая структура наполнителя должна способствовать повышению проводимости композитного материала.

Зависимость удельной электропроводности пленок хитозана от содержания ОСУНТ приведена на рис. 3.

Из приведенной на рис. 3 зависимости видно, что при увеличении содержания ОСУНТ от 0.5 до $1.0 \mathrm{wt} . \%$ проводимость композитной пленки увеличивается с $10^{-7}$ до $10^{-2} \mathrm{~S} / \mathrm{m}$. Резкий рост проводимости материала при небольшом изменении содержания наполнителя свидетельствует о формировании проводящего кластера, состоящего из ОСУНТ.

Повышение содержания наполнителя до $3 \mathrm{wt} . \%$ приводит к дальнейшему росту проводимости, однако скорость ее увеличения несколько снижается. Как видно из данных СЭМ (рис. 2,g,h), при таком содержании ОСУНТ распределение по объему композитной пленки анизометричных частиц наполнителя меняется. Видны трубки, расположенные не только в плоскости пленки, но и перпендикулярно ей. Этим можно объяснить снижение скорости роста проводимости, измерение которой проводили в плоскости пленки.

В работе [22] показано, что электропроводность ненаполненной хитозановой пленки составляет $10^{-11} \mathrm{~S} / \mathrm{m}$. Проводимость кожи находится в диапазоне от $10^{-5}$ до $10^{-2} \mathrm{~S} / \mathrm{m}$ [23]. Таким образом, композитные пленки на основе хитозана, содержащие $0.5-1.0 \mathrm{wt} \%$ ОСУНТ, обладают электропроводностью, близкой к значениям биологических тканей, в частности, кожи человека. Это позволит использовать полученные материалы в тканевой инженерии.

Биологическая совместимость полимерной матрицы в значительной степени зависит от ее электрофизических свойств [24]. Кроме электропроводности, важной характеристикой полимерных материалов для тканевой инженерии является их диэлектрическая проницаемость. Относительная диэлектрическая проницаемость является коэффициентом пропорциональности между электрическим зарядом и электрическим полем и отражает насколько связанные заряды могут смещаться или поляризоваться под действием электрического поля. Известно [24], что относительная диэлектрическая проницаемость человеческой дермы, основного компонента кожи, составляет от $10^{6}$ до $10^{2}$ в диапазоне частот от $1 \mathrm{kHz}$ до $1 \mathrm{MHz}$, в то время как у эпидермиса, верхнего слоя кожного покрова, диэлектрическая проницаемость постоянна и равна $10^{4}$. 


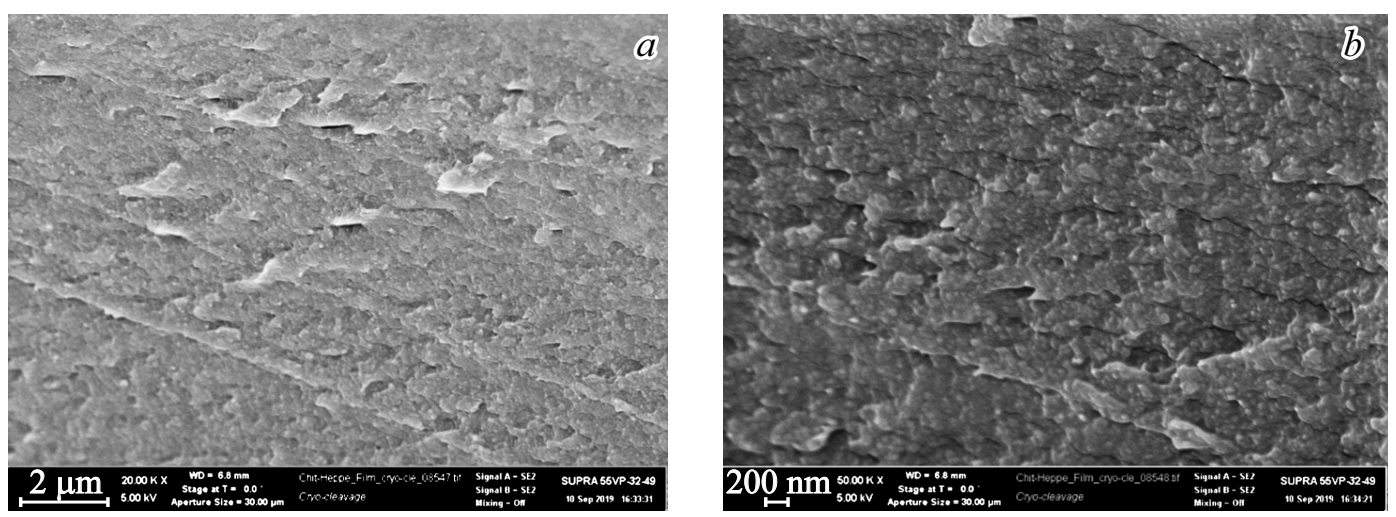

Chitosan

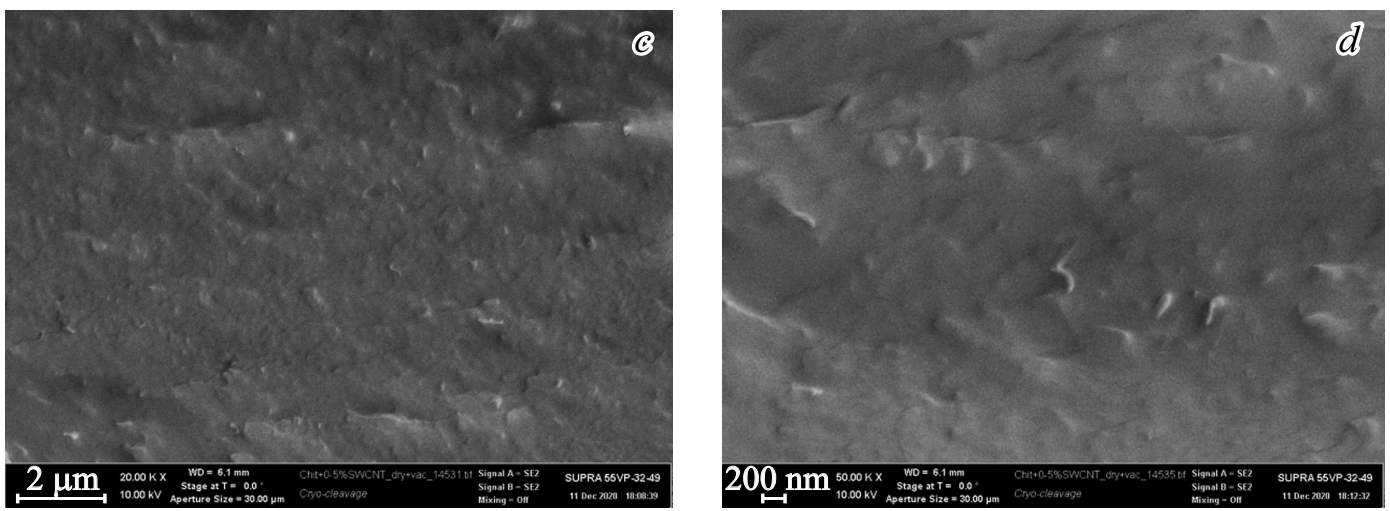

$0.5 \%$ SWCNT

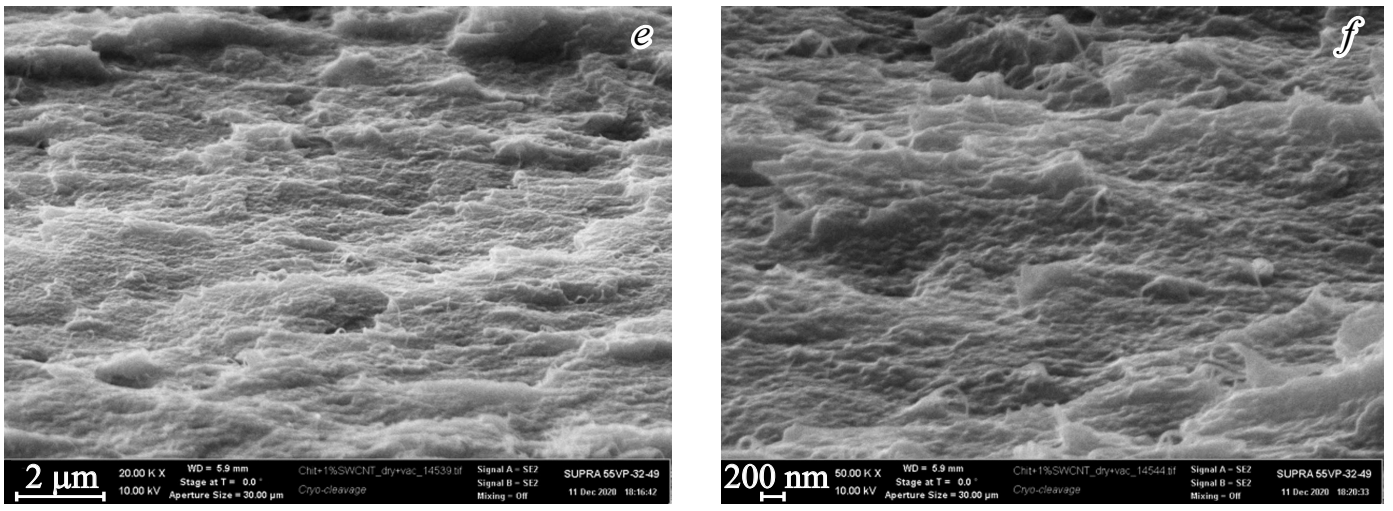

$1.0 \%$ SWCNT

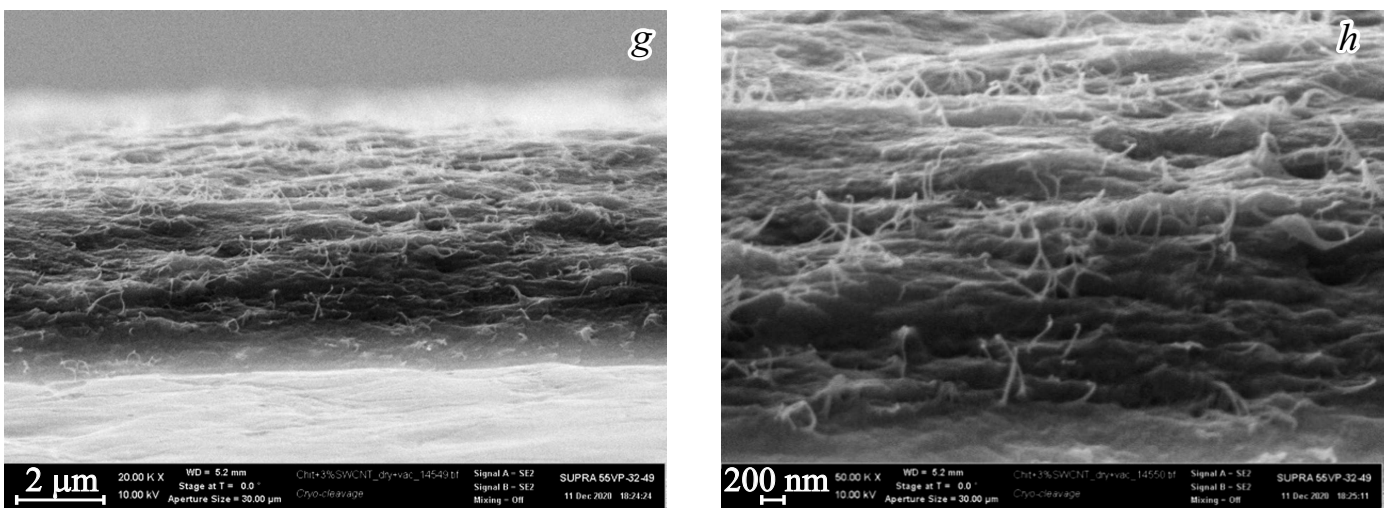

$3.0 \%$ SWCNT

Рис. 2. Микрофотографии сколов в жидком азоте хитозановой пленки $(a, b)$ и композитных пленок, содержащих ОСУНТ $(c-h)$. 


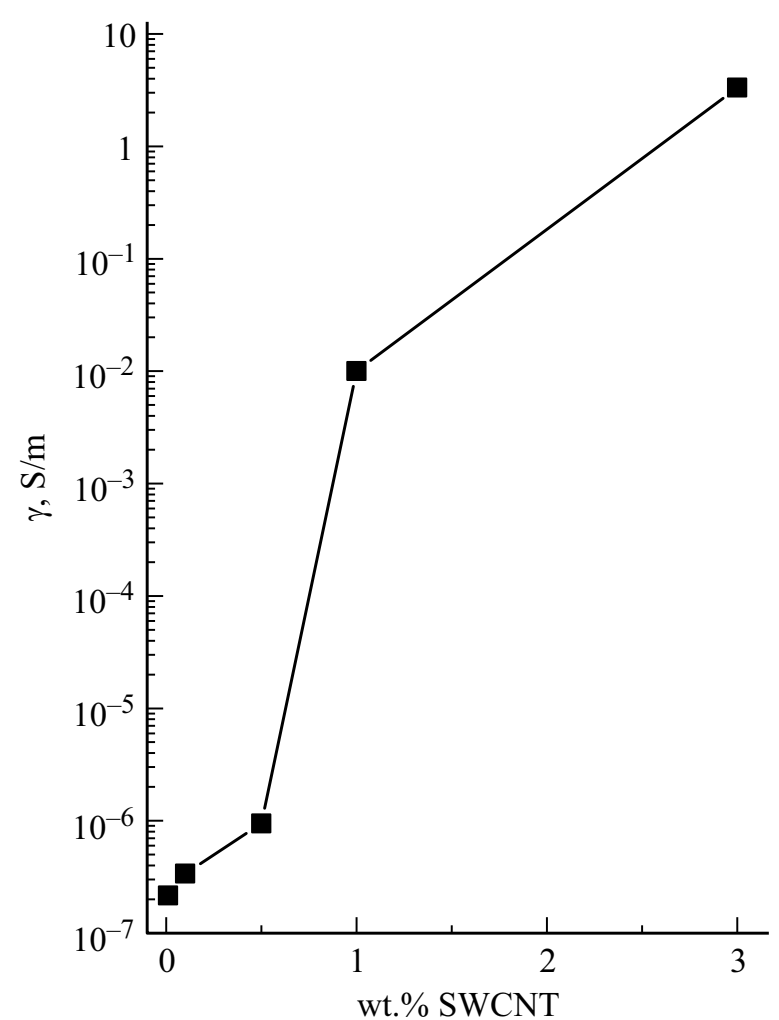

Рис. 3. Изменение объемной электропроводности композитных пленок на основе хитозана от содержания ОСУНТ.

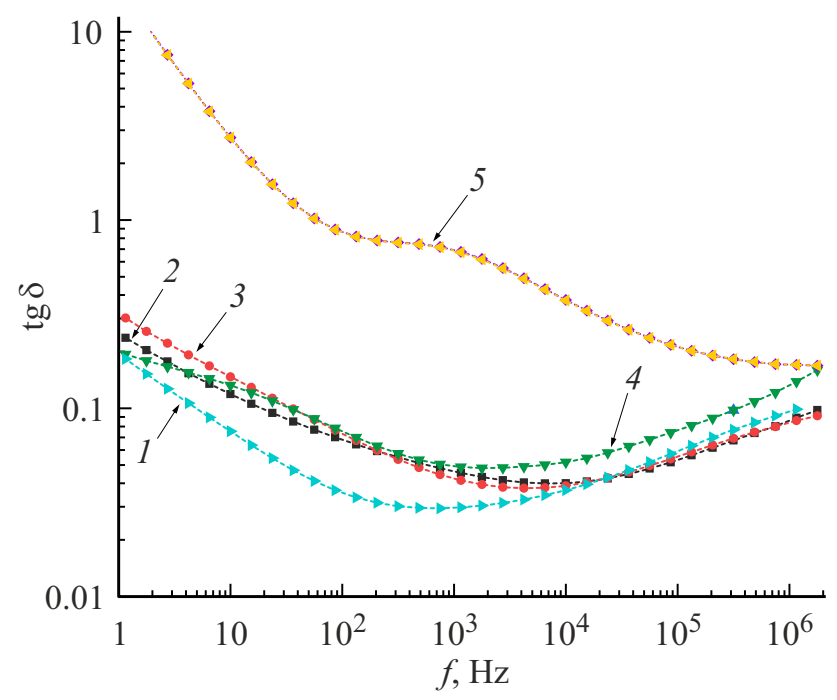

Рис. 4. Зависимость тангенса угла механических потерь пленок хитозана, содержащих 0 (1), 0.01 (2), 0.1 (3), 0.5 (4), 1.0 wt.\% (5) ОСУНТ, от частоты электрического поля.

Результаты измерений диэлектрических характеристик композитных пленок на основе хитозана и ОСУНТ представлены на рис. 4.

На засимостях $\operatorname{tg} \delta(f)$ (рис. 4) показано, что пленки чистого хитозана имеют наименьшие потери 0.03 при $1 \mathrm{kHz}$; при увеличении концентрации ОСУНТ ди- электрические потери возврастают до 0.68. Диэлектрические потери пленки с $1 \%$ ОСУНТ резко возрастают за счет высокой проводимости. Максимум на рис. 4 (кривая 5) по всей вероятности связан с поляризацией Максвелла-Вагнера-Силларса (МВC) [25]. Взаимодействие ОСУНТ и хитозана можно объяснить моделью, представляющей систему микроконденсаторов, где хитозан - диэлектрик, а ОСУНТ - обкладки конденсатора. Эта модель описана в работе [26], где проведены результаты экспериментов и моделирования с использованием MBC.

Из рис. 5 следует, что при увеличении концентрации ОСУНТ в пределах $0-0.5$ wt.\% диэлектрическая проницаемость при $1 \mathrm{MHz}$ возрастает от 4.4 до 5.7. Увеличение содержания трубок до $1 \mathrm{wt} . \%$ приводит к существенному росту диэлектрической проницаемости при низких частотах, при этом ее величина снижается с увеличением частоты поля.

Как известно, под действием переменного электрического поля происходит поляризация макромолекул полимера [27]. Введение в полимерную диэлектрическую матрицу анизометричных углеродных частиц, обладающих парамагнитными свойствами, приводит к возникновению вторичного излучения, которое образуется при взаимодействии их с внешним полем [25]. Наличие в хитозановой матрице ОСУНТ, которые как и все углеволокнистые материалы являются парамагнетиками, способствует увеличению поляризации за счет вторичного излучения. Это снижает диэлектрические свойства композитного материала, способствует повышению ее электропроводности, что подтверждают данные, приведенные на рис. 3.

Диссипативные процессы поглощения и рассеяния как первичного, так и вторичного электромагнитного излучения приводят к существенному увеличению диэлектрической проницаемости пленки, содержащей $1.0 \mathrm{wt} . \%$,

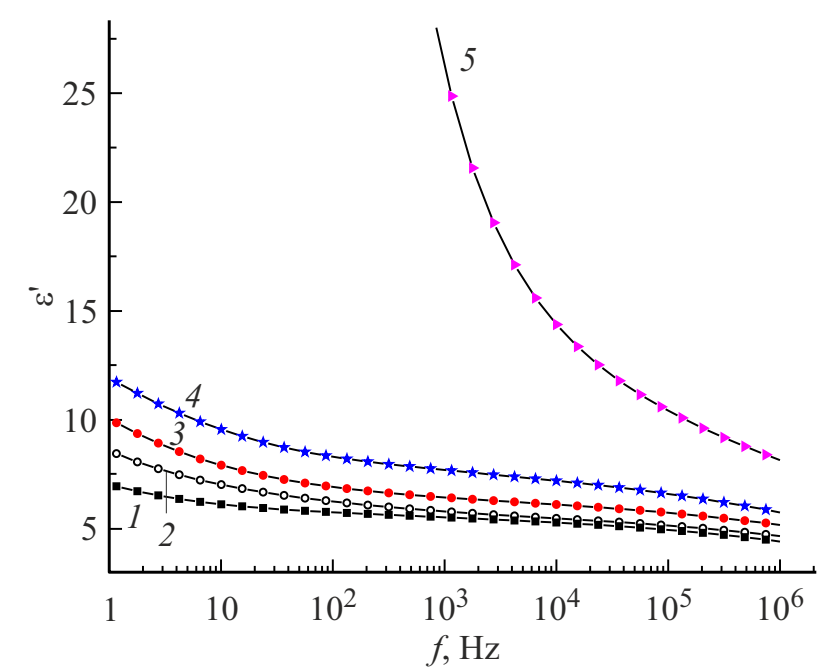

Рис. 5. Зависимость относительной диэлектрической проницаемости пленок хитозана, содержащих 0 (1), 0.01 (2), 0.1 (3), 0.5 (4), 1.0 (5) wt.\% ОСУНТ, от частоты электрического поля. 


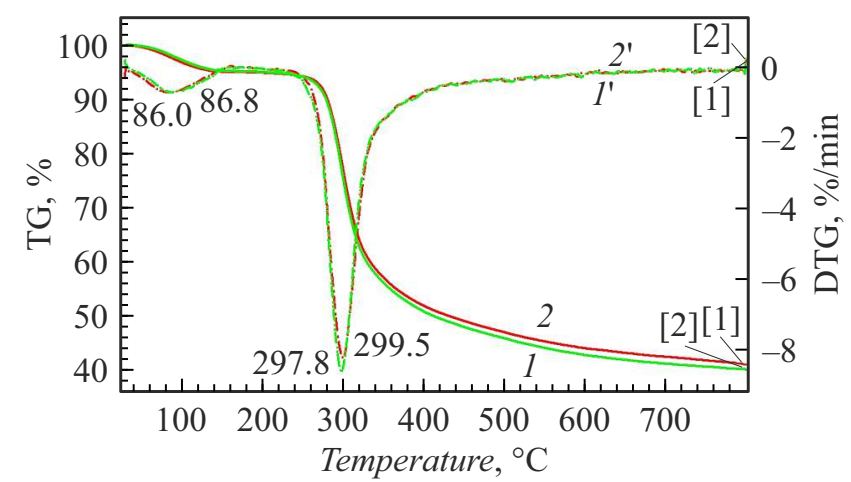

Рис. 6. Термогравиметрические и дифференциальные термогравиметрические кривые пленки из хитозана $\left(1,1^{\prime}\right)$ и композитной пленки, содержащей 1 wt.\% ОСУНТ $\left(2,2^{\prime}\right)$.

Таблица 1. Термические свойства композитных пленок на основе хитозана и ОСУНТ

\begin{tabular}{c|c|c|c|c}
\hline № & $\begin{array}{c}\text { Содержание } \\
\text { ОСУНТ, \% }\end{array}$ & $\begin{array}{c}\text { Остаточная масса } \\
\left(\text { при } 800{ }^{\circ} \mathrm{C}\right), \%\end{array}$ & $\tau_{5},{ }^{\circ} \mathrm{C}$ & $\tau_{10},{ }^{\circ} \mathrm{C}$ \\
\hline 1 & 0 & 40.13 & 277 & 287 \\
2 & 0.1 & 40.47 & 278 & 286 \\
3 & 0.5 & 41.35 & 278 & 287 \\
4 & 1 & 41.25 & 280 & 289 \\
5 & 3 & 41.47 & 279 & 288
\end{tabular}

на низких частотах по сравнению с чистой хитозановой пленкой. С увеличением частоты излучения в диапазоне от $10^{3}$ до $10^{6} \mathrm{~Hz}$ диэлектрическая проницаемость композитной пленки уменьшается. Результаты по измерению диэлектрической проницаемости согласуются с данными, приведенными в работе [28] для чистого хитозана. На рис. 5 показано, что $\varepsilon^{\prime}$ хитозана составляет от 4.5 до 7 в диапазоне частот от $1 \mathrm{~Hz}$ до $1 \mathrm{MHz}$. Введение ОСУНТ в хитозановую матрицу позволяет достичь более высоких значений диэлектрической проницаемости от 5.5 до 26 при $1 \mathrm{kHz}$, что может существенно повысить совместимость имплатируемой пленки и кожного покрова.

Эффективное использование материалов биомедицинского назначения предполагает возможность их стерилизации. Одним из наиболее распространенных стандартизированных методов стерилизации, является автоклавирование в условиях нагревания до $121^{\circ} \mathrm{C}$, при давлении $1 \mathrm{~atm}$, в течение $30 \mathrm{~min}$. Поэтому в настоящей работе проведено исследование термических свойств композитных пленок из хитозана, содержащих ОСУНТ.

На дифференциальной кривой ДТГ хитозана (рис. 6) можно выделить две области потери массы: $50-150^{\circ} \mathrm{C}$ - область, отвечающая за потерю влаги и остатков растворителя, и $260-360^{\circ} \mathrm{C}$ - область, отвечающая за процесс деструкции хитозана.

Данные эксперимента ТГА с рассчитанными значениями индексов термостойкости $\left(\tau_{5}, \tau_{10}\right)$ представлены в табл. 1.

Термостойкость оценивали по значениям индексов термостойкости $\tau_{5}$ и $\tau_{10}$ температурам, при которых происходит потеря массы 5 и 10\%. Отметим, что все пленки характеризуются высокой термостойкостью. Температура начала их разложения составляет $277-289^{\circ} \mathrm{C}$. Эти температуры существенно выше температур стандартных режимов стерилизации. Введение жаростойкого углеродного наполнителя не влияет на термические характеристики композита. Поэтому хитозановые пленки, содержащие ОСУНТ, могут подвергаться термообработке, в том числе стерилизации при температурах вплоть до $250^{\circ} \mathrm{C}$.

В табл. 2 приведены результаты механических испытаний композитных пленок хитозан-ОСУНТ.

Введение ОСУНТ приводит к повышению прочности и, что особенно важно, снижению хрупкости, о чем свидетельствует рост величины относительной деформации при разрыве композитных пленок. Содержание более 1 wt.\% ОСУНТ снижает прочность композитной пленки, что связано с наличием частиц, оринтированных как в плоскости пленки, так и перпендикулярно ей, что видно на рис. 2 , h.

Следует отметить, что имплантаты различного назначения, а также тканеинженерные конструкции, вживленные в живой организм, испытывают динамические нагрузки, вызанные пульсирующим движением жидких сред - крови и лимфы, а также при знакопеременных нагрузках, сжатии-растяжении мышечной ткани. Поэтому важно знать не только механические характеристики в режиме растяжения или сжатия в стационарном режиме, но и механические характеристики образцов в динамическом режиме нагрузки.

На рис. 7 приведены данные ДМА образцов, полученные при частоте нагружения $v=1 \mathrm{~Hz}$, амплитуде деформации $0.1 \%$. Видно, что с увеличением концентрации ОСУНТ модуль упругости $E^{\prime}(T)$ возрастет от 3 до $4 \mathrm{GPa}$

Таблица 2. Механические характеристики композитных пленок хитозан-ОСУНТ

\begin{tabular}{l|c|c|c}
\hline \multicolumn{1}{c|}{ Пленка } & Прочность при растяжении, МРа & Модуль упругости, GРa & Деформация, \% \\
\hline Хитозан & $124.17 \pm 5.42$ & $2.62 \pm 0.57$ & $38.68 \pm 4.84$ \\
Хитозан+0.1\%ОСУНТ & $157.74 \pm 15.40$ & $3.23 \pm 0.24$ & $46.09 \pm 8.13$ \\
Хитозан+0.5\%ОСУНТ & $179.40 \pm 5.40$ & $3.22 \pm 0.37$ & $57.64 \pm 3.57$ \\
Хитозан+1\%ОСУНТ & $161.04 \pm 7.98$ & $3.35 \pm 0.27$ & $47.14 \pm 2.33$ \\
Хитозан+3\%ОСУНТ & $158.91 \pm 17.23$ & $3.57 \pm 0.26$ & $41.16 \pm 5.82$
\end{tabular}




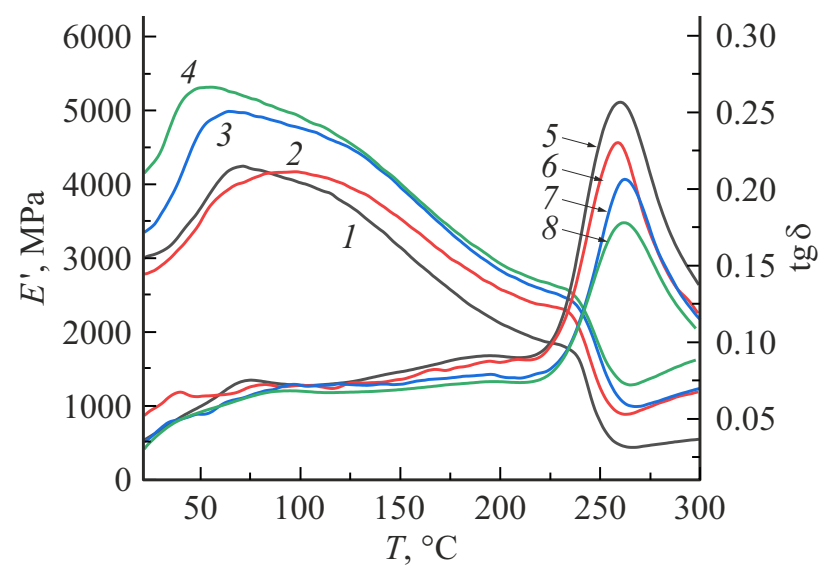

Рис. 7. Зависимости модуля упругости $E^{\prime}$ пленок хитозана, содержащих 0 (1), 0.5 (2), 1 (3), 3 (4) wt.\% ОСУНТ, и соответствующего тангенса угла механических потерь $(5-8)$ от температуры.

при температуре $22^{\circ} \mathrm{C}$. На температурных зависимостях модуля упругости наблюдается резкий спад в области температур размораживания сегментальной подвижности хитозана $\left(246^{\circ} \mathrm{C}\right)$. Рост модуля упругости до $100^{\circ} \mathrm{C}$ и перегибы в этой области температур связан с потерей сорбированной влаги [29].

Кривые $\operatorname{tg} \delta$ (рис. 7) характеризуются широкими максимумами при температурах $250-300^{\circ} \mathrm{C}$, которые определяют температуру стеклования $T_{g}$ композитов. С увеличением концентрации ОСУНТ температуры стеклования незначительно смещаются в высокотемпературную область. Однако термическое разрушение хитозана наблюдается в том же диапазоне температур. Согласно литературным данным [29], $T_{g}$ хитозана близка к температуре его термодеструкции. Температура начала термодекструкции находится (как показано выше) в диапазоне $270-280^{\circ} \mathrm{C}$ для всех исследуемых образцов.

\section{Заключение}

Наличие ОСУНТ в хитозановой пленке способствует упорядочению структуры хитозана и образованию более плотной упаковки макромолекул, что приводит к росту механических характеристик композитных пленок. Показано, что с увеличением содержания ОСУНТ до $1 \mathrm{wt} . \%$ удельная объемная электропроводность увеличивается до $10^{-2} \mathrm{~S} / \mathrm{m}$. Рост диэлектрической проницаемости в области низких частот $1 \mathrm{~Hz}$ обусловлен, в первую очередь, поляризацией МВС. За счет добавления ОСУНТ можно варьировать электрическими и механическими свойствами композитов. Исследование прочностных, деформационных и термических характеристик композитных пленок позволило сделать вывод о возможности их использования в клеточных технологиях, тканевой инженерии, а также при разработке медицинских устройств для диагностики и лечения заболеваний различной этиологии.

\section{Благодарности}

Работа выполнена при финансовой поддержке Российского фонда фундаментальных исследований, грант № 18-29-17011мк.

\section{Конфликт интересов}

Авторы заявляют, что у них нет конфликта интересов.

\section{Список литературы}

[1] T.G. Vladkova. Int. J. Polym. Sci., 2010, 1 (2010). DOI: $10.1155 / 2010 / 296094$

[2] Z. Liu, X. Wan, Z.L. Wang, L. Li. Adv. Mater., 33, 2007429 (2021). DOI: 10.1002/adma.202007429

[3] P. Morgan. Carbon Fibers and Their Composites (CRC Press, 2005). DOI: $10.1201 / 9781420028744$

[4] И.В. Митрофанова, В.И. Мильто, И.В. Суходоло, Г.Ю. Васюков. Бюлл. Сиб. мед., 13, 135 (2014). [I.V. Mitrofanova, I.V. Milto, I.V. Suhodolo, G.Y. Vasyukov. Bull. Sib. Med., 13, 135 (2014). DOI: 10.20538/1682-0363-2014-1-135-144]

[5] B. Guo, P.X. Ma. Biomacromolecules, 19, 1764 (2018). DOI: 10.1021 acs.biomac.8b00276

[6] V.V. Matrenichev, P.V. Popryadukhin, A.E. Kryukov, N.V. Smirnova, E.M. Ivan'kova, I.P. Dobrovol'skaya, V.E. Yudin. Polym. Sci. Ser. A, 60, 215 (2018). DOI: $10.1134 /$ S0965545X18020104

[7] J. Chen, S. Chen, X. Zhao, L.V. Kuznetsova, S.S. Wong, I. Ojima. J. Am. Chem. Soc., 130, 16778 (2008). DOI: $10.1021 / \mathrm{ja} 805570 \mathrm{f}$

[8] J. Cheng, M.J. Meziani, Y.-P. Sun, S.H. Cheng. Toxicol. Appl. Pharmacol., 250, 184 (2011). DOI: 10.1016/j.taap.2010.10.012

[9] B. Pan, D. Cui, P. Xu, C. Ozkan, G. Feng, M. Ozkan, T. Huang, B. Chu, Q. Li, R. He, G. Hu, Nanotechnology, 20, 125101 (2009). DOI: 10.1088/0957-4484/20/12/125101

[10] A. Abarrategi, M.C. Gutiérrez, C. Moreno-Vicente, M.J. Hortigüela, V. Ramos, J.L. López-Lacomba, M.L. Ferrer, F. del Monte. Biomaterials, 29, 94 (2008). DOI: 10.1016/j.biomaterials.2007.09.021

[11] G.S. Lorite, L. Ylä-Outinen, L. Janssen, O. Pitkänen, T. Joki, J.T. Koivisto, M. Kellomäki, R. Vajtai, S. Narkilahti, K. Kordas. Nano Res., 12, 2894 (2019). DOI: $10.1007 / \mathrm{s} 12274-019-2533-2$

[12] V. Lovat, D. Pantarotto, L. Lagostena, B. Cacciari, M. Grandolfo, M. Righi, G. Spalluto, M. Prato, L. Ballerini. Nano Lett., 5, 1107 (2005). DOI: 10.1021/n1050637m

[13] M. Rouabhia, H. Park, S. Meng, H. Derbali, Z. Zhang. PLoS One, 8, 1 (2013). DOI: 10.1371/journal.pone.0071660

[14] B. Reid, M. Zhao. Adv. Wound Care, 3, 184 (2014). DOI: $10.1089 /$ wound.2013.0442

[15] M.N. Ravi Kumar. React. Funct. Polym., 46, 1 (2000). DOI: $10.1016 / \mathrm{S} 1381-5148(00) 00038-9$

[16] E. Stewart, N.R. Kobayashi, M.J. Higgins, A.F. Quigley, S. Jamali, S.E. Moulton, R.M.I. Kapsa, G.G. Wallace, J.M. Crook. Tissue Eng. Pt. C-Meth., 21, 385 (2015). DOI: $10.1089 /$ ten.tec.2014.0338 
[17] J. Yang, G. Choe, S. Yang, H. Jo, J.Y. Lee. Biomater. Res., 20, 1 (2016). DOI: 10.1186/s40824-016-0078-y

[18] B. Huang. Biomanufacturing Rev., 5, 1 (2020). DOI: $10.1007 / \mathrm{s} 40898-020-00009-\mathrm{x}$

[19] I.P. Dobrovol'skaya, P.V. Popryadukhin, A.Y. Khomenko, E.N. Dresvyanina, V.E. Yudin, V.Y. Elokhovskii, S.N. Chvalun, N.N. Saprykina, T.P. Maslennikova, E.N. Korytkova. Polym. Sci. Ser. A, 53, 418 (2011). DOI: $10.1134 / \mathrm{S} 0965545 \mathrm{X} 11050038$

[20] И.П. Добровольская, Л.И. Слуцкер, 3.Ю. Черейский, Л.Е. Утевский. Высокомолек. соед. А, 17 (7), 1555 (1975).

[21] E.N. Dresvyanina, S.F. Grebennikov, I.P. Dobrovol'skaya, T.P. Maslennikova, E.M. Ivan'kova, V.E. Yudin. Polym. Sci. Ser. A, 62, 205 (2020). DOI: 10.1134/S0965545X20030050

[22] A. Kamalov, E. Dresvyanina, M. Borisova, N. Smirnova, K. Kolbe, V. Yudin. Mater. Today Proc., 30, 798 (2020). DOI: 10.1016/j.matpr.2020.02.346

[23] C. Gabriel, S. Gabriel, E. Corthout. Phys. Med. Biol., 41, 2231 (1996). DOI: 10.1088/0031-9155/41/11/001

[24] B. Tsai, H. Xue, E. Birgersson, S. Ollmar, U. Birgersson. J. Electr. Bioimpedance, 10, 14 (2019). DOI: $10.2478 /$ joeb-2019-0003

[25] J.C. Maxwell. A Treatise on Electricity and Magnetism (Cambridge Univer. Press, Cambridge, 2010)

[26] X. Xia, Z. Zhong, G.J. Weng. Mech. Mater., 109, 42 (2017). DOI: 10.1016/j.mechmat.2017.03.014

[27] K.W. Wagner. Archiv f. Elektrotechnik, 2, 371 (1914). DOI: 10.1007/BF01657322

[28] S. Bonardd, E. Robles, I. Barandiaran, C. Saldias, Á. Leiva, G. Kortaberria. Carbohydr. Polym., 199, 20 (2018). DOI: $10.1016 /$ j.carbpol.2018.06.088

[29] E.N. Dresvyanina, I.P. Dobrovol'skaya, V.E. Smirnov, E.N. Popova, E.N. Vlasova, V.E. Yudin. Polym. Sci. Ser. A, 60, 179 (2018). DOI: 10.1134/S0965545X18020049 